\title{
GAMBARAN PERILAKU YANG BERPERAN TERHADAP KONDISI OBESITAS PADA PEREMPUAN DEWASA MUDA DI JAKARTA
}

\author{
Teddy Kurniawan Kawi', Margaretha Purwanti, \& Wieka Dyah Partasari \\ Universitas Katolik Indonesia Atma Jaya Jakarta, Jl. Jend. Sudirman nomor 51, 021-5727615 \\ Korespondensi: \\ le-mail: kurniawankawi@gmail.com
}

\begin{abstract}
This study seeks to understand the behavior that leads to obesity among young adult women in Jakarta, guided by Theory of Reasoned Action (Ajzen \& Fishbein, 1975) and Self-Efficacy Theory (Bandura, 1986) as the framework. This study employed qualitative methodology, participated by three female participants (27-31 years old) and resided in Jakarta area. The results show that although participants were from various background; all of them have similarities in many behavioral aspects that leads to them being obesed. In particular, participants developed an attitude that eating was their coping mechanisms during stress. Related to the subjective norms aspect, participants perceived support from their close relatives but was not demonstrated through the real action. Negative mood and the lack of knowledge about healthy behavior affected their self-efficacy. Biological and environment factors play a pivotal role in shaping obesity. Practically termed, this study outlined a need for tailoring an intervention program that focuses on the attitude, subjective norm, and self-efficacy in reshaping behavior of people, particularly women, with obesity.
\end{abstract}

\author{
Article history: \\ Received 29 November 2017 \\ Received in revised form 29 January 2018 \\ Accepted 24 July 2019 \\ Available online 27 February 2020
}

\author{
Keywords: \\ behavior; \\ obesity; \\ self-efficacy; \\ Theory of Reasoned Action
}

\begin{abstract}
Abstrak - Studi ini bertujuan untuk mengetahui gambaran perilaku yang berperan terhadap obesitas pada perempuan dewasa muda, menurut Theory of Reasoned Action (Ajzen \& Fishbein, 1975) dan teori Self-Efficacy (Bandura, 1986). Penelitian menggunakan pendekatan kualitatif terhadap tiga perempuan dewasa muda (27-31 tahun) yang berdomisili di Jakarta. Hasil penelitian menunjukkan bahwa meskipun tiap partisipan memiliki latar belakang berbeda yang membentuk kondisi obesitas, terdapat kesamaan dalam aspek-aspek yang mendasari perilaku. Pada aspek attitude, partisipan menganggap makan sebagai cara menghadapi kondisi stres. Pada aspek subjective norms, partisipan merasakan dukungan dari orang terdekat, namun tidak ditunjukkan melalui tindakan nyata. Faktor mood yang negatif dan pengetahuan minimal akan perilaku sehat pada setiap partisipan juga memengaruhi keyakinan diri (self-efficacy) dalam berperilaku. Faktor biologis dan lingkungan cukup berperan terhadap pembentukan kondisi obesitas. Hasil studi ini merekomendasikan rancangan intervensi yang berfokus pada attitude, subjective norms, dan self-efficacy dari perilaku yang berperan terhadap kondisi obesitas.
\end{abstract}

Kata Kunci: perilaku, obesitas, keyakinan diri, Theory of Reasoned Action 


\section{PENDAHULUAN}

Selama beberapa dekade terakhir ini, jumlah penderita obesitas di negara-negara maju ataupun berkembang semakin meningkat. Berdasarkan hasil penelitian Insititute for Health Metrics and Evaluation (dalam Marie, dkk, 2014), jumlah orang yang menderita obesitas meningkat menjadi 2.1 milliar tersebar di seluruh dunia. Penyebaran orang yang menderita obesitas tersebut mayoritasnya ada pada negara-negara maju atau yang sedang berkembang (Marie, dkk, 2014). Indonesia sebagai salah satu negara berkembang menduduki peringkat ke-10 sebagai negara dengan masyarakat pengidap obesitas terbanyak ("Tingkat obesitas Indonesia nomor 10 dunia", 2014).

Terdapat beberapa faktor yang melatarbelakangi terjadinya obesitas, seperti: metabolisme tubuh dalam memproses makanan, faktor genetik, faktor psikologis (food crave, rasa bosan, stres), dan faktor lingkungan (akses yang mudah untuk mendapatkan makanan, perubahan gaya hidup menjadi sedentary lifestyle) (Taylor, 2012; Carlson, 2002). Faktor-faktor tersebut dimanifestasikan ke dalam perilaku makan berlebihan yang berdampak pada kalori yang masuk lebih besar. Aktivitas fisik yang minimal membuat kalori yang keluar lebih sedikit, sehingga terjadi penumpukan lemak dan menimbulkan obesitas.

Menurut Ogden (dalam Victoriana, 2012) penderita obesitas memiliki preokupasi terhadap perilaku makan, sehingga menimbulkan perilaku makan yang berlebihan. Makan merupakan kebutuhan dasar manusia untuk dapat bertahan hidup, namun aktivitas tersebut sering kali tidak hanya dilakukan untuk memenuhi kebutuhan dasar itu. Jung (1978) menyatakan bahwa kebutuhankebutuhan dasar biologis manusia, seperti makan, minum, seks, dan keamanan fisik, banyak dipengaruhi oleh faktor-faktor non-biologis. Sebagai contoh, perilaku makan juga sering dilakukan untuk memenuhi kebutuhan sekunder, seperti: melampiaskan rasa marah, rasa sedih, dan perasaan kecewa yang dialami (Taylor, 2012; Carlson, 2002). Makan juga digunakan untuk mengungkapkan perasaan syukur dan bahagia yang dimiliki, seperti: merayakan pernikahan dengan pesta dan jamuan makan (Victoriana, 2012).

Selain perilaku makan, aktivitas fisik juga menjadi fokus perhatian dalam membahas kondisi obesitas. Indonesia merupakan salah satu negara dengan jumlah penduduk terbanyak yang jarang melakukan aktivitas fisik. Penduduk di Indonesia diketahui paling jarang berjalan kaki jika dibandingkan dengan negara-negara lain ("Data ponsel dunia: Orang Indonesia paling malas berjalan kaki”, 2017). Faktor infrastruktur dan kesenjangan sosial dianggap berkontribusi terhadap minimalnya aktivitas fisik. 
Obesitas dapat menuntun kepada penyakit-penyakit kronis, seperti: hipertensi, penyakitpenyakit kardiovaskular, dan diabetes melitus (Nussy, Ratag, \& Mayulu, 2014; Kushner \& Ryan, 2016). Obesitas tidak hanya menuntun kepada dampak negatif terhadap kesehatan fisik, namun juga terhadap kesehatan psikologis, dalam hal ini adalah: stres, depresi, dan rasa rendah diri pada individu dengan obesitas (Klaczynski, Goold, \& Mudry, 2004; Loth, Wall, Larson, \& Neumark-Sztainer, 2015). Selain itu, penderita obesitas juga kerap menerima stigma negatif dari masyarakat, di mana mereka sering dinilai pemalas karena dianggap tidak dapat mengurus diri mereka sendiri (Taylor, 2012).

Berbagai dampak negatif yang dapat diperoleh karena obesitas menjadikan hal ini sebuah perhatian khusus di beberapa negara yang memiliki peningkatan jumlah penderita obesitas. Pemahaman terhadap penyebab utama terjadinya obesitas diperlukan untuk memperoleh penanganan tepat. Oleh karena itu peneliti mencoba untuk memahami perilaku yang mendasari terjadinya obesitas, yakni perilaku makan dan perilaku aktivitas fisik.

Theory of Reasoned Action (TRA) memberikan perspektif yang dapat menjelaskan perilaku manusia (Ajzen \& Fishbein, 1975), termasuk yang berkaitan dengan obesitas. Menurut TRA, perilaku (health behavior) individu merupakan hasil dari intensi atas perilaku (behavioral intention) tersebut. Intensi didasari oleh dua hal, yakni sikap terhadap perilaku (attitudes toward behavior) dan persepsi terhadap norma yang berlaku di sekitar individu (subjective norms toward behavior). Studi ini menggunakan TRA untuk menjelaskan perilaku yang berdampak pada obesitas (retrospective study).

Sikap terhadap perilaku yang memengaruhi intensi didasari oleh kepercayaan (behavioral belief) yang dimiliki individu terhadap hasil (positif maupun negatif) yang dapat diperoleh dari perilaku tersebut. Semakin kuat kepercayaan tersebut, maka semakin besar pengaruhnya terhadap intensi, yang pada akhirnya akan memengaruhi perilaku. Kepercayaan juga memengaruhi norma sosial yang ada di sekitar individu. Dalam hal ini, kepercayaan yang dimaksud adalah kepercayaan individu mengenai pandangan orang lain (normative belief) terhadap perilaku tersebut. Kepercayaan tersebut dapat memiliki pengaruh yang setara atau berbeda, bergantung pada kondisi-kondisi lainnya yang dimiliki oleh individu (seperti pengalaman, interaksi sosial, media sosial) (Ajzen, Albarracin, \& Hornik, 2007).

Untuk lebih lanjut memahami perilaku, studi ini juga menggunakan konsep self-efficacy (Bandura, 1986). Self efficacy (keyakinan diri) merupakan keyakinan individu mengenai kemampuannya dalam mengatur dan berperilaku untuk melakukan tugas tertentu dan mengatasi hambatan-hambatan yang muncul selama melakukan tugas tersebut untuk mendapatkan hasil yang 
diinginkan. Keyakinan diri dianggap sebagai salah satu faktor keberhasilan dalam melakukan perilaku sehat yang membuat individu mempertahankan perubahan perilaku positifnya. Dinamika dan peranan dari kepercayaan (behavioral belief dan normative belief) serta keyakinan diri terhadap perilaku makan dan aktivitas fisik pada individu yang memiliki obesitas ditelusuri dalam penelitian ini.

Adapun rumusan masalah dalam penelitian ini ialah: Bagaimana gambaran perilaku yang berperan terhadap kondisi obesitas pada individu jika ditinjau melalui Theory of Reasoned Action (TRA)?; Bagaimana gambaran self-efficacy yang dimiliki oleh individu terhadap perilaku yang memengaruhi kondisi obesitas?

\section{METODE}

\section{Partisipan}

Penelitian dilakukan di Jakarta dengan melibatkan tiga orang partisipan. Pemilihan partisipan menggunakan teknik purposive sampling, dengan kriteria: 1) memiliki BMI di atas 30,2) berdomisili di Jakarta, 3) berusia antara 18-40 tahun, dan 4) pernah atau sedang mengikuti program penurunan berat badan. Karakteristik partisipan dapat dilihat pada Tabel 1.

Tabel 1.

Karakteristik Partisipan

\begin{tabular}{lccc}
\hline & Partisipan 1 & Partisipan 2 & Partisipan 3 \\
\hline Inisial & $\mathrm{D}$ & $\mathrm{Y}$ & $\mathrm{M}$ \\
Usia & 28 tahun & 31 tahun & 27 tahun \\
Jenis Kelamin & Perempuan & Perempuan & Perempuan \\
Tinggi Badan & $162 \mathrm{~cm}$ & $156 \mathrm{~cm}$ & $158 \mathrm{~cm}$ \\
Berat Badan & $147 \mathrm{~kg}$ & $85 \mathrm{~kg}$ & $103 \mathrm{~kg}$ \\
BMI & 56 & 34.9 & 41 \\
Pekerjaan & Mahasiswi & Karyawan Swasta & Freelancer \\
Status & Belum Menikah & Menikah & Belum Menikah \\
Etnis & Jawa & Tionghoa & Ambon \\
\hline
\end{tabular}

\section{Desain}

Penelitian ini menggunakan pendekatan kualitatif. Data utama diperoleh melalui wawancara mendalam terhadap partisipan. Selain itu, untuk kebutuhan triangulasi data, dilakukan juga pengisian kuesioner dan catatan harian oleh partisipan. 


\section{Prosedur}

Penelitian ini menggunakan wawancara mendalam sebagai teknik pengumpulan data disertai dengan beberapa sumber data lainnya. Teknik wawancara yang digunakan merupakan semistructured interview, dengan beberapa pertanyaan panduan, lalu diperdalam (probing) guna mendapat data yang menyeluruh (Berg, 2007). Panduan wawancara disusun berdasarkan Theory of Reasoned Action (Ajzen \& Fishbein, 1975), dan Self-Efficacy Theory (Bandura, 1986) guna menggali peranan dari perilaku-perilaku yang dimiliki oleh partisipan terhadap kondisi obesitas yang dimiliki.

Selain wawancara, digunakan instrumen tambahan berupa kuesioner, yakni Food Craving Questionnaire - Trait - reduced (FCQ-T-r) yang diterjemahkan dalam versi bahasa Indonesia. FCQT dirancang oleh Cepeda-Benito, dan dikembangkan kembali dalam jumlah butir yang lebih sedikit oleh Meule, Hermann, dan Kubler (2014). Terdapat total 15 butir dengan skala Likert untuk pilihan jawaban dari skala 1-6. Contoh butir yang dimuat, seperti: "Saya merasa selalu memikiran makanan di pikiran saya", "Saya menginginkan makanan ketika saya merasa bosan, marah, atau sedih". Skor yang diperoleh diketahui memiliki hubungan yang positif dengan gangguan makan, BMI (body mass index), dan kegagalan diet (Meule, Hermann, \& Kubler, 2014).

Respons partisipan terhadap kuesioner tersebut memberikan gambaran mengenai perilaku (trait) makan yang selama ini dimiliki dan menjadi salah satu data triangulasi. Triangulasi data dilakukan untuk memvalidasi data wawancara yang sebelumnya diperoleh dari partisipan. Sebelum menyebarkan kuesioner tersebut, peneliti melakukan uji reliabilitas yang dilakukan terhadap 109 partisipan (try out test) dengan hasil yang menunjukkan bahwa alat ukur FCQ-T-r memiliki tingkat reliabilitas Cronbach's Alpha sebesar .866. Selanjutnya, peneliti melakukan uji korelasi antara BMI (Body Mass Index) dan total skor, dan mendapati bahwa terdapat hubungan yang positif antara skor FCQ-T-r dengan BMI $(r=.307 ; p=.001)$. Peneliti mengklasifikasikan total skor yang dimiliki partisipan menjadi tiga kelompok, yakni rendah, sedang, dan tinggi. Total skor di bawah 34 masuk ke klasifikasi rendah; antara 35-57 masuk ke klasifikasi sedang; dan di atas 58 ke klasifikasi tinggi (pengklasifikasian berdasar data try out yang dikumpulkan oleh peneliti).

Selain itu, peneliti juga meminta partisipan untuk mengisi catatan harian yang dibuat berdasarkan kebutuhan penelitian ini. Catatan harian berisi data untuk mengetahui gaya hidup yang melingkupi aktivitas fisik dan pola makan yang dimiliki oleh partisipan. Riwayat kehidupan terkait program atau usaha penurunan berat badan juga dilihat dalam penelitian ini. Informasi tersebut diperoleh dari data demografis yang diisi oleh tiap partisipan sebelum mengikuti wawancara. 
Komisi Etik Universitas Katolik Indonesia Atma Jaya telah melakukan pengkajian terhadap proposal penelitian dan menyatakan bahwa penelitian ini memenuhi standar etika penelitian melalui surat pernyataan dengan nomor 850/III/LPPM-PM.10.05/07/2017.

\section{Teknik Analisis}

Proses analisis data dilakukan dengan melakukan coding dan analisis tematik. Hasil kuesioner FCQ-T-r dan catatan harian diinterpretasikan secara kualitatif guna mendapat gambaran yang lebih menyeluruh terkait perilaku makan dan aktivitas fisik pada partisipan.

\section{ANALISIS DAN HASIL}

\section{Latar Belakang Partisipan}

\section{Partisipan D}

D merupakan anak bungsu dari tiga bersaudara. Ia memiliki seorang kakak perempuan dan seorang kakak laki-laki. Sejak kecil, D selalu berpindah-pindah tempat tinggal bersama ibu dan kakak laki-lakinya karena tugas ayahnya sebagai polisi. Perpindahan akhirnya berhenti saat kakak lakilakinya mengungkapkan keinginannya untuk menetap dan tidak berpindah-pindah lagi. Pada akhirnya, D dan kakak laki-lakinya menetap di Jakarta, bersama seorang pengasuh. Pada saat itu, mereka diberikan uang saku dan memiliki kebebasan dalam melakukan apapun (selama tidak melanggar peraturan ayahnya). Kebebasan itu merupakan salah satu faktor penyebab dirinya mengalami obesitas. Kebebasan yang dimaksud adalah ia dapat memakan apapun tanpa adanya kontrol dan pengawasan dari orang tuanya.

Kakak laki-lakinya juga mengalami obesitas sama seperti dirinya, namun hal itu tidak terjadi terhadap kakak perempuan yang diasuh oleh neneknya. Nenek yang mengasuh kakak perempuannya lebih ketat dalam memelihara pola makan dan memberikan uang saku. Hal lainnya yang membedakan adalah kemudahan dalam hal transportasi yang dimiliki oleh D dan kakak laki-lakinya, namun tidak dimiliki oleh kakak perempuannya, menjadikan kakak perempuannya sebagai sosok yang mandiri sejak kecil.

Peranan lainnya dari orang tua adalah perhatian yang diberikan. Saat kecil, D sering menjadi korban perundungan (bully) oleh teman-teman di sekolahnya. Hal tersebut disebabkan karena logat bahasanya yang berbeda, selain itu, perundungan juga dialaminya karena pekerjaan ayahnya sebagai polisi pada saat itu. Hal-hal tersebut membuat D merasa sedih dan tertekan. Perasaan tertekan cukup 
sering dialami, membuatnya menangis hampir setiap malam. Makan merupakan bentuk pelampiasan dan cara untuk mengatasi perasaan tersebut. Cara yang dilakukan D untuk mengatasi perasaan negatif yang dihadapinya tersebut terus dilakukan dan menjadi pola dalam dirinya yang berdampak pada peningkatan berat badannya.

\section{Partisipan Y}

Y merupakan anak pertama dari lima bersaudara. Pengalaman masa kecil Y yang berhubungan dengan peningkatan berat badannya adalah kebiasaan orang zaman dulu yang senang jika anak-anak makan banyak. Y menambahkan bahwa dirinya juga tidak suka melihat makanan yang tersisa, sehingga ia memiliki kebiasaan untuk menghabiskan makanan, termasuk makanan yang pada saat itu tidak dihabiskan oleh adik-adiknya.

Y adalah orang yang tergolong stress eater karena ia akan makan saat ia merasa stres. Stres yang dialami juga membuatnya malas untuk beraktivitas. Pola ini telah terjadi sejak ia berkuliah karena saat ia harus mengerjakan tugas hingga pagi, ia akan memilih makanan untuk menemaninya bekerja. Setelah ia lulus kuliah dan mulai bekerja, Y mengatakan bahwa pekerjaannya juga membuatnya stres, dan kembali memilih makan sebagai cara mengatasi stres tersebut.

Setelah bekerja, Y memiliki kebebasan yang sebelumnya tidak ia miliki saat berkuliah. Sebagai contoh, dalam segi finansial, ia dapat membeli apapun yang ia inginkan, tanpa harus merasa sungkan kepada orang tuanya. Kebebasan ini juga berdampak terhadap kenaikan berat badannya. Setelah menikah, Y kembali mengalami kenaikan berat badan. Hal ini disebabkan karena ia dan suaminya sama-sama senang makan. Suami Y yang juga berpostur besar memiliki kebiasaan untuk makan berkali-kali, dan hal tersebut turut dilakukan oleh Y. Y menambahkan bahwa ia hanya akan menolak untuk makan apabila ia merasa sangat kenyang.

\section{Partisipan M}

M merupakan anak kedua dari tiga bersaudara, yang semuanya merupakan anak perempuan. Ayahnya berasal dari Ambon dan ibunya berasal dari Solo. Sejak kecil dirinya tinggal bersama kakek dan nenek dari pihak ibu. M mengatakan hal tersebut terjadi karena ayah dan ibunya sibuk bekerja, sehingga waktu yang ada untuk merawat anak-anak sangat terbatas.

Selama tinggal bersama kakek dan neneknya, M mengatakan bahwa orang tuanya jarang mengunjungi, ayahnya akan mendatangi dan menjemputnya sekali dalam setahun. Hal ini menjadikan 
M memiliki hubungan yang kurang dekat dengan orang tuanya. Di sisi lain, hal tersebut juga menjadikannya sebagai individu yang mandiri dan tidak bergantung kepada orang lain karena ia dididik untuk selalu mandiri dan bekerja sebelum mendapatkan hasil atau sesuatu yang diinginkan. Kakek dan neneknya merupakan sosok yang tegas dalam mendidik mereka, dan ketegasan tersebut berlaku dalam segala hal. Berbeda dengan orang tuanya, yang menurut $\mathrm{M}$ sangat permissive dan memperbolehkan ia dan saudara-saudaranya untuk melakukan apa saja. Sejak kecil, M juga tergolong sebagai anak yang aktif. Saat bersekolah, ia harus bersepeda untuk mencapai sekolahnya yang ada di kota. M mengaku bahwa ia senang bersepeda pada saat ia berada di Solo karena udaranya yang bersih dan minim polusi. Sejak berpindah ke Jakarta, ia mengaku tidak pernah bersepeda. Menurutnya, polusi dan kondisi jalanan yang ada di Jakarta tidak memungkinkan baginya untuk bersepeda. Hal tersebut menurutnya merupakan awal mula kenaikan berat badannya.

Selain itu, kebebasan yang diterimanya dari orang tua, dalam hal mengonsumsi makanan juga menjadi faktor lain yang turut berpengaruh dalam kenaikan berat badannya. Ayah dan ibunya tidak pernah mempermasalahkan makanan apapun yang ia inginkan dan untuk mendapatkannya, M hanya perlu meminta. Hal tersebut berbeda dari keterbatasan yang diterimanya saat ia tinggal bersama kakek dan neneknya.

Faktor genetik turut berperan dalam kenaikan berat badannya. M mengatakan bahwa keluarga dari pihak ayahnya memiliki postur fisik yang besar. Hal tersebut menurun kepadanya serta saudarasaudaranya yang lain. Hal tersebut semakin terlihat semenjak ia pindah ke Jakarta.

\section{Sikap yang Menentukan Perilaku (Attitude towards Behavior)}

\section{Partisipan D}

D menceritakan bahwa kemauan orang tuanya lebih banyak berperan dalam keikutsertaannya pada berbagai program penurunan berat badan. Kemauan tersebut dituruti oleh D karena ia menganggap bahwa patuh terhadap orang tua merupakan hal yang wajib dilakukan. Salah satunya adalah dengan mengikuti program diet golongan darah. D mengatakan bahwa sebelum mengikuti program diet ini, ia dan orang tuanya pergi ke Singapura untuk mengikuti beberapa tes dan memeriksa kesehatannya secara umum. Selama mengikuti dan menjalankan program ini, D mengaku bahwa ia tidak memiliki ekspektasi apapun, D mengatakan bahwa ia hanya mengikuti kemauan orang tuanya yang juga turut serta dalam menjalankan program diet tersebut. 
“..sekarang gw ngerasa goal-nya itu adalah memuaskan keinginan nyokap, even kadang harus mengorbankan keinginan gw sendiri..,kayak gitu tuh.. kalo di agama gw, kalo mau jadi anak yang mulia di mata Tuhan, harus nurut sama orang tua.."

Keinginan yang berasal dari luar diri tersebut menurut D memengaruhi kegagalannya dalam melakukan diet. D menambahkan, keinginan berkaitan dengan komitmen yang dimiliki oleh individu dalam melakukan sesuatu dan apabila keinginan tersebut bukan berasal dari dalam diri, maka komitmen untuk mempertahankan perilaku akan menjadi lebih sulit.

Metode lain yang pernah dilakukan oleh D adalah operasi. D menceritakan, pada awalnya, orang tuanya mengetahui bahwa di luar negeri terdapat metode sedot lemak yang mampu mengurangi berat badan secara signifikan. Berdasarkan kabar tersebut, orang tua D meminta D untuk mencobanya. D mengaku bahwa ia tidak memiliki keinginan untuk melakukannya, namun ia tetap menuruti keinginan orang tuanya untuk berangkat dan mencobanya. Setelah tiba dan berkonsultasi dengan dokter yang ada di sana, $\mathrm{D}$ diberitahu bahwa ia tidak dapat mengikuti prosedur sedot lemak tersebut karena berat badannya yang melebihi batas maksimal, namun D diberikan alternatif lain, yakni operasi, tepatnya bypass lambung. Operasi tersebut dilakukan dengan memasangkan alat khusus kepada lambung, guna membatasi jumlah makanan yang masuk ke dalam tubuh, menjadikan orang terkait memiliki perasaan kenyang lebih cepat.

D mengatakan bahwa sebelum melakukan operasi tersebut, dokter sempat menyarankan untuk menetap di sana selama setahun dan mendapat penanganan lanjutan, agar operasi yang dilakukan dapat memberikan hasil yang optimal. Penanganan lanjutan yang dimaksudkan dokter berupa program diet dan aktivitas fisik. Dokter juga menanyakan keseriusan D dalam mengikuti prosedur lain yang dilakukannya setelah operasi dan pada saat itu, D menyanggupinya karena ia merasa tidak mungkin untuk menolak atau mengatakan tidak.

Setelah operasi dilakukan, D menetap selama tiga bulan, sebelum kembali ke Indonesia. Setelah kembali, D menceritakan bahwa ia telah mengidamkan makanan Indonesia, dan melampiaskan perasaannya tersebut dengan memakan apapun yang ia inginkan. Namun, D menambahkan, keinginan tersebut terganggu dengan adanya alat yang dipasang dalam tubuhnya tersebut. Alat tersebut membuat dirinya tidak dapat makan dalam jumlah yang banyak, bahkan perasaan mual sering muncul setiap kali ia memakan sesuatu, yang menyebabkannya mengeluarkan makanan tersebut. D mengaku merasa frustrasi dan marah akan kondisinya saat itu. 
“...jadi ya udah, berangkatlah kita kesana.. even gw kayak berat hati, apa sih ini, kok gw kayak kelinci percobaan banget.. adalah rasa marah sebenernya..”

“..trs pas gw pulang indo, waktu balik indo, lu kangen apa, makan donk.. trs akhirnya makan, tapi ini (alat) mengganggu gw, gw marah sebenarnya, karna gabisa makan cepet, makan cepet gw muntah, makan ga alus gw muntah, saking marahnya, gw makan aja, gw telen aja, karna pada akhirnya gw tau akan muntah.."

D menceritakan bahwa ia juga mencoba olahraga. D sempat mengikuti beberapa tempat pelatihan, namun terdapat beberapa faktor yang menyebabkannya keluar dari tempat tersebut. Menurut D, pada saat itu, ia dan teman-temannya yang mendaftarkan diri ke tempat pelatihan tersebut hanya ingin mengikuti tren yang sedang berlangsung dan hal itu menurutnya menyebabkan dirinya tidak rutin menjalankan aktivitas tersebut.

“..orang banyak ga percaya, gw orangnya senang berkeringat.. Cuma kadang ngelakuin itu kan emang males ya.."

“..temen2 gw di s1, bukan support yg gimana2.. nge-gym bareng, cuma buat ikut2an aja,, bukan typical nge-gym yg serius..”

Berdasarkan pernyataan tersebut, terlihat bahwa D cenderung dipengaruhi oleh faktor eksternal, baik itu yang berasal dari keluarga, maupun teman-temannya. Ketika D merasa bahwa lingkungannya tersebut tidak lagi memberikan dukungan (dalam bentuk tindakan nyata), maka hal tersebut akan memengaruhi perilaku D.

\section{Partisipan Y}

Y mengaku bahwa ia memiliki postur tubuh yang besar sejak masa sekolah dulu. Y menambahkan bahwa ia tergolong 'besar' dibanding teman-teman perempuannya. Oleh karena itu, ia telah mencoba diet sejak dulu, namun hal tersebut tidak berhasil dilakukannya. Y menambahkan bahwa diet yang dilakukan memengaruhi mood yang dirasakannya. Y mengaku menjadi lebih mudah marah, ataupun curiga.

Y menceritakan pengalamannya berhasil menurunkan berat badan dengan melakukan diet garam. Ia melakukan diet tersebut saat akan melangsungkan pernikahan. Y berhasil menurunkan berat badannya dari 75 kilogram menjadi 70 kilogram. Namun, keberhasilan tersebut tidak berlangsung lama karena $\mathrm{Y}$ mengaku menjadi lebih moody dan mudah lelah, sehingga ia dan suaminya memutuskan untuk menghentikannya.

Selain melakukan diet, Y juga mencoba olahraga dalam menurunkan berat badannya. Y sempat memilih untuk melakukan olahraga di gym, namun ia tidak dapat mempertahankan gaya hidup 
tersebut untuk waktu lama. Y mengatakan bahwa ia sering merasa lelah setelah bekerja dan tidak dapat melanjutkan untuk berolahraga. Oleh karenanya, Y merasa mengeluarkan biaya yang sia-sia untuk pusat kebugaran tersebut, sehingga ia memutuskan untuk berhenti.

"Semenjak udah kerja, itu udah gak bisa olahraga lagi, karena abis pulang kerja itu stres, capek, jadi udah gak bisa lagi.."

"Udah pulang kerja, capek, kupikir yaudah, ngapain olahraga, yaudah, tidur.."

Setelah berhenti dari gym, Y mencoba berjalan ringan di pagi hari selama kurang lebih 1 jam sebagai cara untuk menurunkan berat badan. Cara tersebut dilakukan karena ia juga telah mendapat saran dari dokter bahwa berat badannya tidak mendukung untuk lari atau olahraga berat lainnya. Aktivitas berjalan ringan tersebut juga tidak bertahan lama karena $\mathrm{Y}$ mengaku sering terlambat untuk bangun ataupun merasa malas untuk melakukannya.

\section{Partisipan M}

M mengatakan bahwa ia tergolong stress eater yang berarti bahwa ia memakan sesuatu sebagai coping terhadap stres yang dihadapi. Cara ini mulai dilakukannya sejak ia pindah ke Jakarta. Sebelumnya, M mengaku cara yang dipakai untuk mengatasi stresnya adalah dengan bersepeda dan membersihkan rumah. Semenjak pindah, $M$ tidak lagi bersepeda. M menambahkan bahwa hal itu tidak dapat dilakukannya karena kondisi lingkungan yang menurutnya tidak memungkinkan untuk itu. Selain itu, mood yang dirasakan saat berada di Jakarta turut memengaruhi keinginannya untuk melakukan aktivitas bersepeda. Menurut M, kondisi cuaca yang lebih panas dibanding di Solo membuatnya mudah untuk terpancing amarah, hingga ia memilih untuk tidak beraktivitas.

“..aku lebih ke stress eating, misal aku abis ketemu kak Teddy aku sebel, ya aku beli makan, terus pas sampe rumah laper lagi, aku bisa makan lagi..”

“..itu dari pindah ke Jakarta.. sebelumnya kalo stress, aku bersih-bersih, trus capek, trus tidur..”

M memiliki pandangan bahwa makan merupakan cara yang tergolong nyaman dalam mengatasi stres. M menambahkan, setelah makan, hal yang selanjutnya ia lakukan adalah tidur, lalu ia akan lupa akan perasaan stres yang sebelumnya dirasakan. M menceritakan bahwa selama tinggal bersama kakek dan neneknya, ia merasakan kehidupan yang sulit karena jumlah dan variasi makanan yang terbatas. Selain itu, jika ia ingin 'jajan', maka ia harus bekerja (membersihkan rumah) terlebih dahulu untuk mendapatkan uang saku. Setelah kepindahannya ke Jakarta, M menceritakan bahwa ia 
mendapatkan kebebasan dari kedua orang tuanya, yang berarti bahwa ia bebas memakan apapun yang diinginkan. Selain itu, M juga menemukan cara mengatasi stres yang sebelumnya tidak ia sadari, yakni dengan makan. M mengaku, semenjak di Jakarta, setiap kali ia merasakan stres, ia akan mencari makanan. Pola tersebut akhirnya membentuk pandangannya terkait perilaku makan, sehingga saat ini, M mengaku sulit untuk melakukan diet. Pengalamannya terkait diet menimbulkan efek yang menurutnya efek 'withdrawal' karena ia akan merasakan craving akan makanan tertentu dan keinginan tersebut sulit untuk diatasi.

\section{Norma Subjektif Tentang Perilaku (Subjective Norms Regarding Behavior) Partisipan D}

Menurut partisipan D, orang-orang di sekitarnya memiliki keinginan yang kuat agar ia menurunkan berat badannya dan hal tersebut mengganggu dirinya, terlebih saat keinginan tersebut dipaksakan kepadanya. Pengalaman yang D miliki sebelumnya membuat ia kini merasa tidak nyaman terhadap orang-orang yang memintanya untuk menurunkan berat badannya.

“..semakin gw di push, semakin gw naik, dan itu selalu,, itu gw perhatiin.. gatau kenapa.. kayak ada gini loh, semakin lu menekan gw, semakin ga akan gw penuhin keinginan lu.."

D mengatakan bahwa tidak semua orang yang ia kenal dan memiliki hubungan dekat dengannya menginginkan agar ia menurunkan berat badannya. D menambahkan bahwa yang mereka maksud adalah bahwa mereka dapat menerima D sebagai D apa adanya, tanpa harus mengubah apapun. Menurut D, hal ini membuatnya merasa nyaman berada di sekitar orang-orang tersebut karena ia tidak merasakan tekanan apapun.

"Kalo sekarang, temen2 selalu ingetin, Cuma ga pernah maksa.. itu yang buat gw nyaman sama mereka."

D menceritakan bahwa selama ini usaha-usaha yang dilakukannya untuk menurunkan berat badan tidak didasari oleh keinginannya sendiri, melainkan keinginan yang berasal dari luar diri, seperti pada saat ia mengikuti diet golongan darah, operasi, dan olahraga. 


\section{Partisipan Y}

Partisipan Y memiliki pandangan bahwa keluarganya, terutama ayah dan ibunya, sangat mendukungnya untuk menurunkan berat badan. Dukungan tersebut ditunjukkan dengan ajakan untuk melakukan olahraga bersama. Y menceritakan bahwa ayah dan ibunya sering mengajak dirinya untuk jalan pagi atau berlari ringan bersama. Meskipun demikian, tidak jarang juga orang tua Y selalu menganjurkan dirinya untuk tidak berusaha terlalu keras dalam diet makan yang ia lakukan.

“..namanya orang tua ya.. kalo uda nongol, meskipun lagi diet juga ga mungkin kamu ga makan kan.. ya gitu..”

Y mengatakan bahwa suaminya juga mendukungnya untuk menurunkan berat badan. Suami Y juga memiliki postur tubuh yang besar, maka setiap kali $\mathrm{Y}$ ingin berusaha menurunkan berat badan, $\mathrm{Y}$ akan mengajak suaminya. Meskipun suaminya memberikan dukungan, namun Y mengatakan bahwa suaminya mudah terpancing ke dalam godaan. Godaan yang Y maksud adalah saat mereka mengunjungi sebuah mall yang berisi makanan-makanan yang mereka suka. Meskipun Y mengaku dapat menahan diri untuk tidak ikut tergoda, namun tidak jarang juga ia mengikuti kehendak suaminya dan ikut makan bersama.

“..iya, jadi tiap kali ke mall tuh pasti beli makan.. sekarang lebih agak terkontrol ya, tapi kalo dulu tuh liat apa yang menarik pasti beli makan.."

“..kalo ke bioskop nonton, pasti selalu beli popcorn, meskipun udah kenyang, tetep musti ada popcorn..”

\section{Partisipan M}

M mengatakan bahwa ibunya sangat mendukungnya selama ini dalam melakukan usaha diet. M menceritakan bahwa setiap kali ia ingin menurunkan berat badan, ia mengatakan keinginannya tersebut ke ibunya dan respons yang diberikan ibunya adalah membelikan bahan makanan yang dapat membantu proses diet, serta memonitor perkembangan diet yang dijalani.

Lain halnya dengan anggota keluarga yang lain, $M$ mengaku tidak terlalu dekat dengan anggota keluarganya yang lain. Ayahnya telah almarhum, sedangkan kakak dan adiknya memang tidak terlalu memiliki hubungan yang dekat dengannya. $\mathrm{M}$ juga mengatakan bahwa ia merupakan tipikal orang yang cenderung melakukan hal berlawanan dari yang dianjurkan oleh orang lain dan hal ini sering dilakukannya saat kakak perempuannya berusaha memberitahukan sesuatu mengenai dietnya. 
"aku typical yang kalo orang bilang A, aku ke B.. kalo orang bilang B, aku ke C.."

\section{Keyakinan Diri (Self Efficacy)}

\section{Partisipan D}

Pada saat mengikuti diet golongan darah, D melihat bahwa program tersebut tidak berlangsung lama dalam keluarganya. Hal tersebut disebabkan karena faktor eksternal seperti pekerjaan ayahnya dan faktor biaya yang dikeluarkan selama menjalankan program tersebut. Kegagalan yang dialami oleh keluarganya tersebut (vicarious experience) membuat D juga pada akhirnya meyakini bahwa ia tidak dapat lagi meneruskan program tersebut seorang diri.

"Itu kayak gabisa dijalani dengan strict juga, jadi kayak menurut gw ya lu nya juga gabisa, kenapa gw harus ngikutin.. jadi menurut gw sangat ga efektif, karena juga lama2... yang paling lama ngikutin itu gw, mereka uda engga."

Usaha selanjutnya yang dilakukan oleh D, yang juga mengalami kegagalan adalah operasi bypass. Hasil yang positif sempat diperoleh oleh D pada awal ia menjalankan operasi ini, namun physical and emotional state yang dirasakannya pada saat itu cukup memengaruhi keyakinan yang dimilikinya sehingga ia tidak dapat mempertahankan pola hidup yang dianjurkan oleh dokter yang menanganinya. D merasakan mual setiap kali makan dan ia harus makan secara perlahan. Hal itu membuatnya menderita dan merasa frustrasi karenanya.

“..trs pas gw pulang Indo, waktu balik Indo, lu kangen apa, makan donk.. terus akhirnya makan, tapi ini (alat) mengganggu gw, gw marah sebenarnya, karena gabisa makan cepet, makan cepet gw muntah, makan ga alus gw muntah, saking marahnya, gw makan aja, gw telen aja, karna pada akhirnya gw tau akan muntah.."

D juga sempat melakukan konsultasi dengan dokter nutrisi yang direkomendasikan oleh temannya. Selama menjalankan diet yang dianjurkan oleh dokter tersebut (social persuasion), D mengakui bahwa berat badannya berhasil berkurang. Namun, D memutuskan untuk tidak melanjutkannya karena ia merasa tidak diapresiasi oleh dokter yang menanganinya. Selain itu, D merasa pada saat itu kondisinya tidak memungkinkan untuk mengikuti program diet secara tertib. D menceritakan bahwa pada saat itu ia memiliki jam makan yang tidak menentu karena kesibukannya sebagai mahasiswi baru, sedangkan dokter tersebut menegaskan bahwa programnya harus dilakukan secara tepat waktu. 
Usaha olahraga yang dilakukan sebelumnya juga tidak menunjukkan hasil yang efektif.D menjelaskan bahwa saat itu keinginannya untuk berolahraga cukup banyak dipengaruhi oleh temantemannya yang juga mengikuti kegiatan olahraga tersebut (vicarious experience). Ketika temantemannya tidak lagi menjalani aktivitas olahraga tersebut, D juga berhenti melakukannya.

\section{Partisipan Y}

Keyakinan yang dimiliki oleh partisipan Y dalam usaha menurunkan berat badan dipengaruhi oleh beberapa faktor. Pada awalnya, Y mencoba melakukan diet, namun usaha tersebut dipengaruhi oleh kondisi mood atau emosi yang ia miliki, sehingga ia tidak dapat mempertahankannya. Kegagalan dalam melakukan diet tersebut telah berkali-kali ia alami dan hal tersebut membentuk mastery experience yang juga memengaruhi setiap usaha diet yang ia lakukan setelahnya.

Metode lain yang Y lakukan adalah olahraga. Ia sempat memilih gym sebagai sarana untuk melakukan olahraga tersebut, namun hal tersebut tidak berlangsung lama karena kondisi fisik (lelah sehabis kerja) yang ia rasakan setiap kali akan melakukan olahraga. Alternatif lain yang dilakukan Y adalah berjalan ringan, yang juga merupakan saran dari dokter yang ia kunjungi (social persuasion). Saran tersebut ia lakukan dan orang tuanya turut mendukung dan melakukan usaha tersebut bersamanya. Namun, Y merasa orang tuanya memiliki fisik yang lebih kuat dibanding dirinya, sehingga menyebabkannya tidak lagi memiliki motivasi yang kuat untuk melakukan aktivitas jalan ringan bersama orang tuanya (vicarious experience).

\section{Partisipan M}

M mulai mengalami kenaikan berat badan secara signifikan saat semester akhir kelas 3 SMK karena saat itu tugas-tugas yang ia kerjakan cukup memberikan tekanan kepadanya, sehingga ia melakukan coping dengan cara makan. Kondisi tersebut menjadikan keberhasilan M dalam mengurangi berat badan tidak berlangsung lama.

“..kurang sih kurang..Cuma waktu akhir kelas tiga, kan banyak paper, udah gitu masuk kuliah juga kan banyak tugas.. udah de, jadi berantakan lagi.."

Setelah ia lulus SMK, ia berkuliah, dan mulai tinggal sendiri di sebuah kos. M mengaku tidak dapat mengatur pola makan dan pola tidur yang dimilikinya dengan baik sejak di kos. Hal tersebut dipengaruhi oleh faktor kesibukan dirinya sebagai mahasiswi di jurusan sastra, sebab tugas yang ia 
kerjakan saat itu sangat banyak dan dengan kondisi tersebut, ia terpaksa harus begadang. Kondisi tersebut turut memengaruhi jam makannya yang menjadi tidak teratur.

M mengatakan bahwa meskipun ia baru tidur di pagi hari (jam 5-6) karena tugas yang ia kerjakan, ia juga memiliki kebiasaan untuk bangun sekitar jam 7 pagi. M mengaku tidak dapat melanjutkan tidur dan biasanya hal tersebut memengaruhi kondisi emosi yang dimilikinya seharian. M mengaku menjadi lebih mudah untuk marah.

“..aku udah terbiasa tidur itu cuma 1 jam 2 jam..dari kuliah dulu gitu, karna tugas, dulu banyak banget..."

"..ngga sih,, paling efeknya cuma ke temperamen ya.."

Physical and emotional state yang dimiliki oleh $\mathrm{M}$ berperan besar terhadap keyakinan yang dimiliki M dalam melakukan usaha dietnya. Hal ini juga ditambah dengan faktor mastery experience, yakni kegagalan dalam mempertahankan hasil diet yang pernah diperoleh. $\mathrm{M}$ juga menceritakan pengalamannya ketika ia kembali ke Solo selama setahun. Selama di Solo, ia mengaku berhasil menurunkan berat badannya karena kebiasaannya untuk bersepeda saat bepergian. Keberhasilan tersebut juga dapat dipengaruhi oleh kondisi physical and emotional state yang dimiliki oleh $\mathrm{M}$ selama berada di Solo, di mana ia merasakan kondisi physical and emotional yang lebih baik jika dibandingkan dengan selama berada di Jakarta.

\section{Triangulasi Data}

Berdasarkan hasil tes $F C Q-T-r$, ketiga partisipan memiliki skor yang termasuk dalam klasifikasi tinggi (di atas 58 dari maksimum skor 90). Masing-masing memiliki skor sebagai berikut: partisipan pertama 67; partisipan kedua 64; dan partisipan ketiga 64. Hasil tersebut menunjukkan trait yang dimiliki oleh tiap partisipan dalam aspek food craving. Hal ini juga dapat menunjukkan usaha yang dilakukan dalam menurunkan berat badan cenderung mengalami kesulitan, baik yang dilakukan sebelumnya, maupun yang akan datang. Hasil tersebut mendukung analisis berdasarkan hasil wawancara yang sebelumnya telah dilakukan.

Triangulasi data juga dilakukan dengan melihat catatan harian yang berisi aktivitas, asupan kalori, serta perasaan terkait yang diisi oleh masing-masing partisipan dalam rentang waktu 1 minggu. Partisipan 1, D, memiliki pola makan yang terbagi hingga lima kali dalam sehari, hal itu termasuk makanan ringan, serta minuman yang mengandung kalori. Aktivitas yang dilakukan oleh partisipan D menunjukkan minimnya gerak yang dilakukan, mayoritas dipenuhi oleh kegiatan duduk (mengerjakan tugas, berbicara dengan orang lain, makan, berkendara). Selain itu, D juga menuliskan 
perasaan yang ia rasakan. Diketahui bahwa perasaan cemas dan sedih lebih sering dirasakan oleh partisipan D dalam kurun waktu tersebut. Perasaan-perasaan negatif tersebut dapat disebabkan oleh event yang dialami oleh $\mathrm{D}$.

Pola makan partisipan Y terbagi menjadi dua hingga tiga kali dalam sehari, namun dalam sekali makan, Y dapat makan dalam jumlah banyak atau memakan berbagai jenis makanan atau minuman yang mengandung kalori cukup besar. Aktivitas sehari-hari yang dilakukan oleh Y banyak dihabiskan dengan kegiatan duduk (bekerja, berkendara). Selain itu, perasaan yang biasanya dirasakan oleh partisipan $\mathrm{Y}$ adalah stres. Y mengatakan bahwa stres tersebut lebih banyak ditimbulkan oleh pekerjaan yang dimilikinya.

Partisipan M memiliki pola makan yang terbagi menjadi 4-5 kali dalam sehari. Pola makan tersebut banyak diisi dengan makanan yang mengandung karbohidrat dan gula, seperti nasi, kentang, roti, serta berbagai jenis minuman manis. Selain itu, kegiatan yang dilakukan M selama seminggu penuh diisi dengan aktivitas seperti bermain game, tidur, dan menonton televisi. M tidak banyak menuliskan mengenai perasaan yang dirasakannya. M lebih menjelaskan perasaan yang dialaminya sebagai 'bad mood' dan 'hyper'. Hal tersebut mungkin berkaitan dengan suatu kejadian yang dialami oleh M selama jangka waktu 1 minggu tersebut.

\section{DISKUSI}

Ketiga partisipan dalam penelitian ini memiliki sikap yang sama terhadap perilaku makan. Masing-masing partisipan berpandangan bahwa makan merupakan cara yang dilakukan untuk mengatasi stres atau emosi negatif yang dimiliki. Hal tersebut menunjukkan bahwa perilaku makan telah menjadi strategi menghadapi masalah yang dimiliki. Perilaku tersebut dipilih dan dipertahankan oleh masing-masing partisipan guna mengatasi permasalahan yang mereka hadapi dan mereka akan merasa lebih baik setelahnya. Jika melihat pada prinsip functionalism yang digagaskan dalam teori evolusi Darwin dan diadaptasikan kepada pendekatan perilaku, maka dapat dikatakan bahwa perilaku dimunculkan setelah melalui proses eliminasi. Perilaku yang dianggap dapat beradaptasi terhadap kondisi lingkungan yang ada akan dipertahankan (Farmer \& Chapman, 2008).

Perilaku tersebut semakin dipertegas dengan adanya penguatan (reinforcement) yang merupakan konsekuensi yang ditimbulkan dari perilaku tersebut (Skinner, dalam Farmer \& Chapman, 2008). Dalam hal ini, perilaku makan yang digunakan sebagai cara untuk mengatasi masalah dianggap sebagai cara yang paling adaptif karena memunculkan efek yang menenangkan dalam 
waktu yang singkat. Meski terlihat berhasil, namun tidak jarang cara yang digunakan tersebut memiliki efek jangka panjang yang negatif terhadap individu (Farmer \& Chapman, 2008).

Partisipan juga memiliki kepercayaan bahwa orang terdekat mendukung mereka untuk menjalani usaha menurunkan berat (subjective norms regarding behavior), namun dukungan tersebut tidak ditunjukkan dalam bentuk perilaku nyata, sehingga hal tersebut memengaruhi intensi mereka untuk terus menjalani perilaku. Hal tersebut dapat terkait dengan locus of control yang dimiliki oleh tiap partisipan. Locus of control merupakan kepercayaan yang dimiliki oleh individu atas sebuah kejadian atau hasil yang terjadi dalam kehidupan mereka. Kepercayaan tersebut dapat terbagi menjadi dua, yakni internal dan eksternal. Neymotin dan Nemzer (2014) mengungkapkan bahwa obesitas dan locus of control memiliki hubungan dan diketahui juga bahwa individu yang memiliki locus of control eksternal memiliki tingkat kortisol yang lebih tinggi dibanding individu dengan locus of control internal. Kortisol merupakan hormon yang memiliki kaitan dengan stres, dan stres cenderung menjadi stimulus untuk perilaku makan berlebihan. Selain itu, Neymotin dan Nemzer (2014) juga menemukan bahwa individu dengan locus of control internal memiliki kecenderungan lebih tinggi untuk berhasil dalam menjalankan usaha menurunkan berat badan. Meskipun terlihat negatif, namun individu dengan locus of control eksternal memiliki benefit tersendiri, yakni peranan orang lain dapat menjadi signifikan dalam intervensi yang diberikan. Peran serta dukungan dari orang lain memiliki makna yang lebih besar terhadap individu dengan locus of control eksternal.

Keyakinan diri partisipan untuk berperilaku juga merupakan aspek yang memengaruhi pengalaman tiap partisipan terkait usaha menurunkan berat badan. Glasofer, dkk (2013) menemukan bahwa remaja perempuan yang memiliki tingkat keyakinan diri yang rendah cenderung lebih rentan untuk mengalami kehilangan kontrol dalam perilaku makan, sehingga dapat menimbulkan obesitas dalam jangka panjang. Selain itu, kesediaan makanan dan kemudahan untuk mendapatkannya menjadikan makan sebagai sesuatu yang sulit dikontrol apabila individu tidak memiliki regulasi diri yang baik. Regulasi diri diketahui memiliki hubungan positif dengan keyakinan diri individu tersebut.

Peningkatan dalam regulasi diri juga dipercaya dapat meningkatkan keyakinan diri seseorang. Annesi dan Gorjala (2010) mendapati bahwa peningkatan pada regulasi diri dapat meningkatkan keyakinan diri, baik terhadap perilaku makan, maupun aktivitas fisik. Hal lain yang didapati adalah mood dapat menjadi perantara dalam hubungan antara regulasi diri dan keyakinan diri atas perilaku makan. Suasana hati yang negatif akan memengaruhi regulasi diri serta keyakinan diri yang dimiliki oleh individu terhadap perilaku yang dijalankan. Hal tersebut tercermin dalam penelitian ini karena tiap partisipan menggunakan makan sebagai cara untuk mengatasi suasana hati negatif yang dimiliki. 
Kondisi emosi negatif yang dialami oleh tiap partisipan yang kemudian diatasi dengan cara makan membentuk asosiasi dalam diri partisipan. Hal tersebut menjadikan partisipan merasa apabila mereka tidak melakukan perilaku makan tersebut, maka emosi negatif yang dialami tidak akan teratasi. Kondisi ini memengaruhi keyakinan diri yang dimiliki untuk mengubah perilaku makan menjadi pola perilaku yang lebih sehat (Annesi \& Gorjala, 2010). Hal ini juga dapat dipengaruhi oleh faktor pengetahuan yang dimiliki oleh partisipan. Pengetahuan yang dimaksud adalah pengetahuan terkait pola hidup yang lebih sehat, baik dalam perilaku makan, maupun aktivitas fisik.

Faghri dan Buden (2015) menemukan adanya hubungan antara pengetahuan dan keyakinan diri terhadap perilaku serta nilai prediksi terhadap BMI yang dimiliki oleh individu. Semakin rendah pengetahuan dan keyakinan diri, maka semakin tinggi BMI yang dimiliki oleh individu. Hasil penelitian tersebut dapat menjelaskan kondisi yang dialami oleh partisipan dalam penelitian ini, yakni tiap partisipan cenderung memiliki pengetahuan yang minimal terkait lingkungan serta pola perilaku sehat.

Ketiga partisipan berjenis kelamin perempuan. Faktor gender memiliki pengaruh terhadap usaha menurunkan berat badan, terutama perilaku yang dilakukan oleh partisipan. Hallam, Boswell, DeVito, dan Kober (2016) menunjukkan bahwa gender memiliki pengaruh terhadap perbedaan dalam food craving yang dimiliki. Perbedaan tersebut dapat berupa jenis makanan yang diidamkan, frekuensi, intensitas, serta regulasi diri pada saat mengalami ngidam (mengidamkan makanan). Mengidam merupakan sebuah keinginan yang kuat untuk memakan sesuatu. Hal ini telah menjadi salah satu prediktor yang kuat terhadap kenaikan berat badan atau kegagalan dan keberhasilan seseorang dalam menurunkan berat badan (Boswell \& Kober, dalam Hallam, Boswell, DeVito, \& Kober, 2016).

Setiap partisipan dalam penelitian ini memiliki skor yang tergolong tinggi pada skala food craving trait. Hasil tersebut menunjukkan bahwa tiap partisipan cenderung mengalami ngidam dengan ada atau tidak adanya stimulus makanan di sekitarnya. Adanya trait tersebut dapat disebabkan oleh kemudahan untuk mendapatkan makanan yang dimiliki tiap partisipan (Hallam, Boswell, DeVito, \& Kober, 2016). Kemudahan tersebut dapat berupa lingkungan yang banyak menyediakan berbagai jenis makanan ataupun kemudahan untuk mendapat makanan dengan cara memesan melalui teknologi yang ada saat ini.

Trait food craving yang dimiliki oleh tiap partisipan dalam penelitian ini juga mendukung hasil penelitian sebelumnya, yang mendapati bahwa perempuan memiliki kecenderungan untuk memiliki skor food craving yang lebih tinggi dibanding laki-laki. Frekuensi serta intensitas dari 
ngidam yang dialami perempuan lebih tinggi dibanding laki-laki. Jenis makanan yang diidamkan oleh perempuan lebih mengarah kepada makanan atau minuman yang manis, sedangkan laki-laki lebih mengarah kepada makanan yang gurih, seperti daging, ikan, dan telur. Perempuan juga diketahui lebih sulit dalam mengontrol keinginan makan ketika keinginan tersebut muncul, baik yang disebabkan karena adanya stimulus makanan, maupun tidak. Hal tersebut dapat disebabkan oleh perubahan hormonal. Perempuan yang mengalami menstruasi setiap bulannya akan mengalami perubahan hormon yang dapat menimbulkan peningkatan dalam perilaku makan (Hallam, Boswell, DeVito, \& Kober, 2016).

Selain perilaku makan, aktivitas fisik juga merupakan perilaku yang dilihat dalam penelitian ini. Ketiga partisipan dalam penelitian ini menunjukkan minimnya aktivitas fisik dalam kesehariannya. Aktivitas fisik yang minimal yang terjadi pada perempuan dapat disebabkan karena adanya perbedaan peran gender. Penelitian yang dilakukan sebelumnya mendapati perbedaan dalam frekuensi dan intensitas aktivitas fisik pada anak perempuan dan anak laki-laki. Hasil yang sama juga ditemukan pada laki-laki dan perempuan dewasa yang telah berumur lebih dari 70 tahun. Meskipun aktivitas fisik pada umumnya akan berkurang seiring bertambahnya usia, namun pada perempuan, pengurangan tersebut menjadi lebih bermakna (negatif) jika dibanding dengan laki-laki (University of Exeter, 2009). Adapun faktor kesehatan menjadi alasan yang paling banyak digunakan oleh perempuan saat ingin melakukan olahraga ataupun aktivitas fisik lainnya (Azevedo, dkk, 2007). Hal tersebut juga tercermin dalam penelitian ini, di mana ketiga partisipan memiliki keinginan untuk menjalankan olahraga ringan karena faktor kesehatan yang mulai memengaruhi kualitas hidup mereka masing-masing.

\section{SIMPULAN DAN SARAN}

\section{Simpulan}

Obesitas merupakan sebuah kondisi yang terbentuk melalui sebuah proses yang termanifestasi melalui perilaku. Hasil dalam penelitian ini mendapati bahwa perilaku yang berperan terhadap kondisi obesitas dipengaruhi oleh beberapa faktor seperti, kepercayaan terhadap perilaku, kepercayaan terhadap keinginan orang lain mengenai perilaku, dan keyakinan diri dalam menjalankan perilaku. Selain itu, faktor biologis dan juga faktor lingkungan (peran gender dan budaya) turut berperan dalam pembentukan obesitas. 


\section{Saran Teoretis}

Penelitian ini memiliki keterbatasan dalam variasi partisipan, di mana ketiga partisipan dalam penelitian ini adalah wanita. Berdasarkan diskusi penelitian yang telah dibahas sebelumnya, diketahui bahwa gender memiliki peranan tersendiri terhadap kondisi obesitas. Oleh karena itu, penelitian selanjutnya dapat mengambil partisipan dengan karakter (gender, usia) yang lebih bervariasi, guna mendapat gambaran yang lebih luas terkait kondisi obesitas.

Penelitian selanjutnya juga dapat mempertimbangkan untuk mengkaji lebih dalam aspek biologis (genetik, metabolisme) dan aspek sosial (peran gender, budaya) pada individu yang mengalami obesitas, guna mendapat hasil yang lebih optimal terkait pemahaman kondisi obesitas, yang pada akhirnya dapat membantu dalam merancang sebuah penanganan yang lebih efektif terhadap kondisi obesitas.

\section{Saran Praktis}

Berdasarkan hasil penelitian, dapat dirancang sebuah program intervensi yang bertujuan untuk mengubah gaya hidup yang dimiliki oleh individu yang mengalami obesitas dengan berfokus pada strategi untuk meningkatkan kesadaran, pengetahuan, dan perubahan kebiasaan (perilaku).

\section{REFERENSI}

Ajzen, I., Albarracin, D., \& Hornik, R. (2007). Prediction and change of health behavior: applying the reasoned action approach. Mahwah, NJ: LEA.

Ajzen, I., \& Fishbein, M. (1975). Belief, attitude, intention, and behavior: An introduction to theory and research. Reading, MA: Addison-Wesley.

Annesi, J. J., \& Gorjala, S. (2010). Relations of self regulation and self-efficacy for exercise and eating and BMI change: A field investigation. BioPsychoSocial Medicine, 4(10), 1-6. doi: 10.1186/1751-0759-4-10

Azevedo, M. R., Araújo, C. L. P., Reichert, F. F., Siqueira, F. V., da Silva, M. C., \& Hallal, $\quad$ P. C. (2007). Gender differences in leisure-time physical activity. International Journal of Public Health, 52(1), 8-15. doi: 10.1007/s00038-006-5062-1

Bandura, A. (1986). Social foundations of thought and action: A social cognitive theory. Englewood Cliffs, NJ: Prentice-Hall.

Berg, B. L. (2007). Qualitative Research for Social Sciences (6th ed.). Boston, MA: Pearson. 
Carlson, N. R. (2002). Foundations of Physiological Psychology (5th ed.). Boston, MA: Allyn and Bacon.

Data ponsel dunia: Orang Indonesia paling malas berjalan kaki. (2017). BBC Indonesia. Ditemu kembali dari http://www.bbc.com/indonesia/majalah-40577906

Faghri, P., \& Buden, J. (2015). Health behavior knowledge and self-efficacy as predictors of body weight. Journal of Nutritional Disorders \& Therapy, 5(3). doi: 10.4172/2161-0509.1000169

Farmer, R. F., \& Chapman, A. L. (2008). Behavioral interventions in cognitive behavior therapy: Practical guidance for putting theory into action. Washington, DC: American Psychological Association.

Glasofer, D., Haaga, D. \& Hannallah, L., Field, S. E., Kozlosky, M., Reynolds, J. C., Yanovski, J. A., \& Tanofsky-Kraff, M. (2013). Self-efficacy beliefs and eating behavior in adolescent girls at-risk for excess weight gain and binge eating disorder. The International Journal of Eating Disorders. 46(7). doi: 10.1002/eat.22160

Hallam, J., Boswell, R. G., DeVito, E. E., \& Kober, H. (2016). Gender-Related Differences in Food Craving and Obesity. The Yale Journal of Biology and Medicine, 89(2), 161-173.

Jung, J. (1978). Understanding human motivation: A cognitive approach. New York, NY: Macmillan. Klaczynski, P. A., Goold, K. W., \& Mudry, J. J. (2004). Culture, obesity stereotypes, self-esteem, and the "thin ideal": A social identity perspective. Journal Of Youth And Adolescence, 33(4), 307-317. doi: 10.1023/B:JOYO.0000032639.71472.19

Kushner, R. F., \& Ryan, D. (2016). Screening and Diagnosis. Journal Of Family Practice, 65(7). S2S4.

Loth, K., Wall, M., Larson, N., \& Neumark-Sztainer, D. (2015). Disordered eating and psychological well-being in overweight and nonoverweight adolescents: Secular trends from 1999 to 2010. International Journal Of Eating Disorders, 48(3), 323-327.

Marie, NG., dkk. (2014). Global, regional, and national prevalence of overweight and obesity in children and adults during 1980-2013: A systematic analysis for the Global Burden of Disease Study 2013. The Lancet, 384 (9945), 766-781. doi:10.1016/S0140-6736(14)60460-8

Meule, A., Hermann, T., \& Kübler, A. (2014). A short version of the Food Cravings QuestionnaireTrait: The FCQ-T-reduced. Frontiers in Psychology, 5(190), 1-10. doi: 10.3389/fpsyg.2014.00190

Neymotin, F., \& Nemzer, L. R. (2014). Locus of Control and Obesity. Frontiers in Endocrinology, 5. 159. doi: $10.3389 /$ fendo. 2014.00159 
Nussy, C. Y., Ratag, G. A. E., \& Mayulu, N. (2014). Analisis upaya-upaya penurunan berat badan pada mahasiswi angkatan 2010 fakultas kedokteran Universitas Sam Ratulangi Manado. Jurnal Kedokteran Komunitas dan Tropik, 2(2).

Taylor, S. E. (2012). Health psychology (8th ed.). New York, NY: McGrawHill.

Tingkat obesitas Indonesia nomor 10 dunia. (2014). BBC Indonesia. Ditemu kembali dari http://www.bbc.co.uk/indonesia/majalah/2014/05/140529_iptek_indonesia_obesitas.shtml

University of Exeter. (2009, January 8). Lifelong Gender Difference In Physical Activity Revealed. ScienceDaily. Diunduh dari www.sciencedaily.com/releases/2009/ 01/090105190740.htm

Victoriana, E. (2012). Rancangan program pengontrolan berat badan bagi individu yang mengalami obesitas. (Makalah tidak dipublikasikan). Universitas Kristen Maranatha, Indonesia. 